\title{
A Genetic Wallace's Line ACross Wyoming - GENETIC STRUCTURE OF NORTH AMERICAN ROSY-FINCHES
}

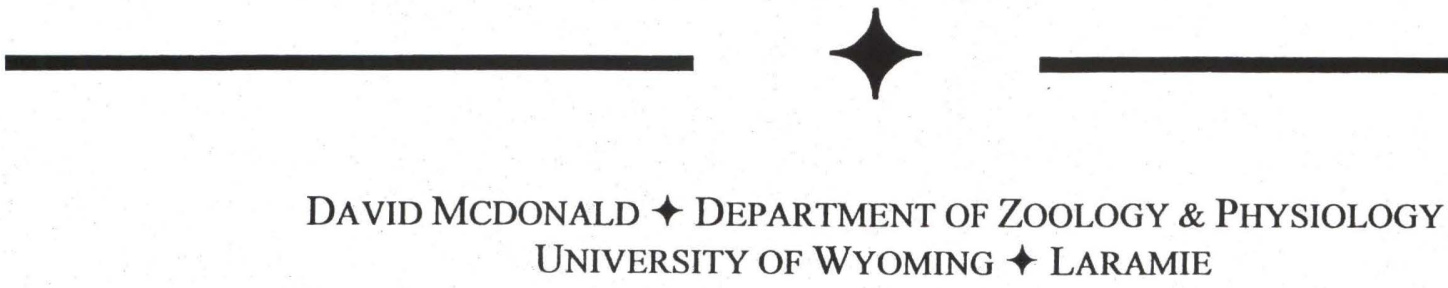

\section{$\downarrow \quad$ INTRODUCTION}

North American rosy-finches (genus Leucosticte) are currently classified by the American Ornithologists' Union (1998) as three species - the Brown-capped Rosy-Finch, L. australis, with a breeding range largely restricted to the Colorado Rockies, but extending barely into southeast Wyoming and northern New Mexico, the Black Rosy-Finch, L. atrata, breeding from Utah north through western Wyoming (including GTNP) and west to Idaho and Nevada, and the Gray-crowned RosyFinch, L. tephrocotis, breeding from the Sierra Nevada through the Cascades and from northern Montana through the Rockies to Alaska. Based on previous results for a surprising genetic break for black bears (Ursus americanus) across Wyoming, I was interested in the degree of genetic differentiation among populations of rosy-finches, particularly between Brown-capped Rosy-Finches in Colorado and Black Rosy-Finches in Wyoming. Because the mating system is largely unknown, and because of reports in the literature of highly male-biased sex ratios (e.g., 6 males per female; French, 1959), I was also interested in using genetic markers to assess patterns of parentage in rosy-finches. Because of its striking plumage (often indicative of strong sexual selection) I was particularly interested in the Black Rosy-Finch. Using polymorphic microsatellites (nuclear DNA) we have now analyzed an initial sample of individuals from the three North American forms, including three sets of nestling Black RosyFinches and the behavioral father at one of the nests.

\section{Samples and field effort}

After trying several field locations in the Wind River Range, the Tetons, the Uintas (Utah) and the Beartooth Plateau (WY-MT), we concentrated efforts in the Uintas and the Beartooth Plateau in the summer of 2002 - all within the range of the Black Rosy-Finch. We also conducted adaptive cluster sampling for rosy-finches in two Colorado locations. We sampled nestlings, and the behavioral father attending one of the nests, at two Black Rosy-Finch nests in the Uintas. We also sampled nestlings from a nest on the Beartooth Plateau. Only three other biologists have discovered nests of this species (Miller, 1925; French, 1959; Johnson, 2002 describing nests found in the 1970's). We have also mist netted, banded and blood sampled rosy-finches at various sites in Wyoming and Colorado during the winter - these have included individuals of all three species including two distinguishable forms of the Gray-crowned Rosy-Finch, gray-capped L.t. tephrocotis and gray-hooded L.t. littoralis, which breeds in the Cascades. Unfortunately, these winter samples cannot be assigned to a breeding locality, but they provide information on the genetic variation within the morphologically distinguishable forms. Genotyping of these additional samples is ongoing and will greatly enhance the power of the phylogenetic analysis.

\section{Genetic analyses}

We have developed 7 polymorphic microsatellite loci, for four of which we have analyzed 
the samples currently in hand. We have now analyzed samples from 53 rosy-finches - 24 Black, 16 Brown-capped, 13 Gray-crowned (seven littoralis and six tephrocotis) and one Old World L. arctoa. The loci are highly polymorphic, with three to 21 alleles per locus and expected heterozygosities ranging from 0.66 in the gray-hooded littoralis form of the Gray-crowned Rosy-Finch to above 0.8 in the Black and Gray-crowned forms. With this very high heterozygosity and the relatively small sample sizes, it is very likely that we have not fully revealed all the alleles present in each of the forms. For example, with 21 alleles at a locus, the maximum number of alleles revealed in a sample of six individuals is 12 (assuming all six are heterozygotes). Any preliminary conclusions must therefore be considered entirely provisional. A more robust analysis will require a sample size of at least 50 individuals from each form - at least four times the current sample size.

Recent advances in analysis allow one to construct a phylogenetic tree based on a matrix of pairwise genetic distances between individuals (e.g., Bowcock et al., 1994). Individuals from welldifferentiated taxa are expected to cluster on the same branches of the tree. As can be seen in Fig. 1, the four distinguishable forms do not cluster well together in a phylogenetic tree with the current sample sizes. Instead all major branches contain individuals of all four forms.

Our genetic results provide several interesting insights into the mating system. Individuals from the same nest did tend to cluster together on the phylogenetic tree (Fig. 1). The exception was one nestling and the behavioral father from our first nest in the Uintas. This suggests that multiple paternity within a nest might be occurring. Stronger evidence corroborating this hypothesis comes from detailed analysis of the genotypes within the nests. Three of the four nestlings in the nest from which we sampled the behavioral father lack either of his two alleles at two of the four loci. Paternity exclusion studies assume that exclusion at a single locus could result from an intergenerational mutation, but that exclusion at two loci is exceedingly unlikely to be attributable to mutation rather than extra-pair parentage (Marshall et al., 1998). Further, in the Beartooth Plateau nest, the four nestlings bear five different alleles at one of the loci. We therefore have evidence that extra-pair paternity is reasonably common in rosy-finches - the first glimpse ever into the genetic mating system of this little-studied species.
Rosy-finches are known to nest in loose colonies (Johnson, 2002) - this clustering might be due to limited habitat, or it might suggest polygyny by some males with a loose cluster of affiliated nests. Our genetic data allow us to reject the latter hypothesis. The two nests from the Uintas in Utah were separated by only 40 meters. None of the genotypes of the nestlings in the second nest is compatible with that of the behavioral father at the first nest. Conversely, extrapolating from the genotypes of the nestlings in the second nest to the possible genotypes for the parents at that nest, yields genotypes that are incompatible with the nestlings in the first nest. Thus, it appears that the two different females in these two nests were not engaging in extra-pair copulations with these neighboring males. Instead they appear to be engaging in extra-pair copulations well away from the nest site, most probably at the often distant foraging sites.

\section{$\downarrow \quad$ Literature Cited}

American Ornithologists' Union. 1998. Checklist of North American Birds. Seventh Edition. Baltimore, Maryland.

Bowcock, A.M., Ruiz-Linares, A., Tomfohrde, J., Minch, E., Kidd, J.R., and Cavalli-Sforza, L.L. 1994. High resolution of human evolutionary trees with polymorphic microsatellites. Nature 368: $455-457$.

French, N.R. 1959. Life history of the Black Rosy Finch. Auk 76: 158-180.

Johnson, R.E. 2002. Black Rosy-Finch (Leucosticte atrata). In The Birds of North America, No. 678 (A. Poole and F. Gill, eds.). The Birds of North America, Inc., Philadelphia, PA.

Marshall, T.C., J. Slate, L.E.B. Kruuks, and J.M. Pemberton. 1998. Statistical confidence for likelihood-based paternity inference in natural populations. Mol. Ecol. 7: 639-655.

Miller, F.W. 1925. The nest and eggs of the Black Rosy Finch. Condor 27: 3-7. 


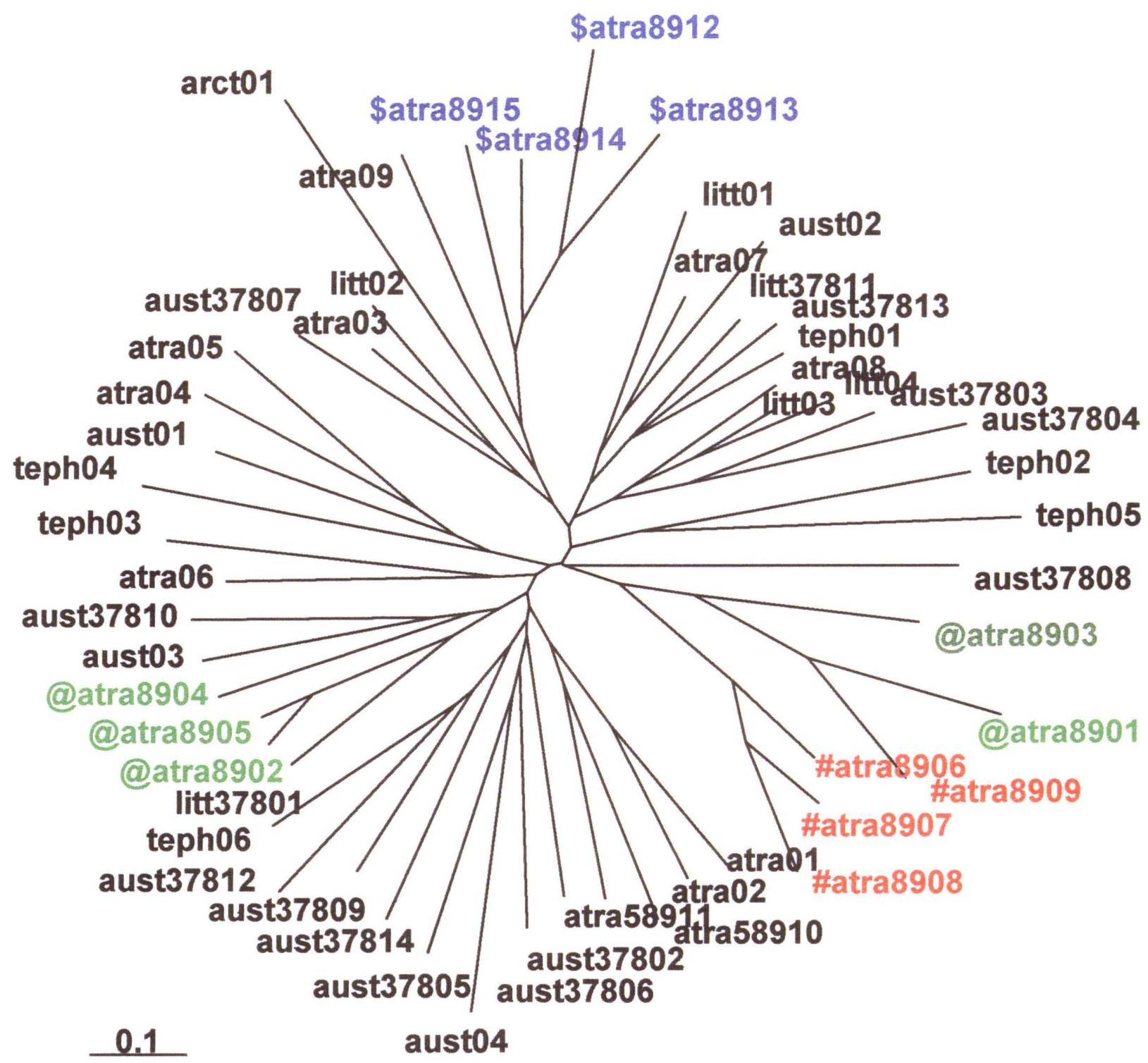

Figure 1. Neighbor-joining tree constructed with the phylogenetic software program PHYLIP based on an allele-sharing matrix (MS Tools Excel toolkit) for 53 individual Leucosticte rosy-finches representing five morphological forms. Symbols: aust: Brown-capped Rosy-Finch, Leucosticte australis; atra: Black Rosy-Finch, L. atrata; teph: graycapped form of Gray-crowned Rosy-Finch, L. tephrocotis tephrocotis;litt: gray-cheeked L.t. littoralis; arct: Old World Leucosticte arctoa. @: nestlings from Nest 1 in the Uintas, UT; @ @: behavioral father from Nest 1 in the Uintas, UT; \# nestlings from Nest 2 in the Uintas, UT; \$ nestlings from Nest 3 on the Beartooth Plateau, WY. 